\title{
Degree of Availability of Community School Standards in Public Schools in Southern Region of Jordan from Teachers' Views
}

\author{
Dr. Suleiman Al- Hajaya \\ Department of Educational Psychology \\ Faculty of Educational Sciences, Tafila Technical University, Jordan \\ E-mail: suhajaya@ttu.edu.jo \\ Hani Kraimeen \\ Department of Educational Psychology, Faculty of Educational Sciences \\ Tafila Technical University, Jordan. \\ E-mail: hani@ttu.edu.jo
}

Received: Feb. 14, 2017 Accepted: April 26, 2017 Published: May 1, 2017

doi:10.5296/jse.v7i2.10734 URL: https://doi.org/10.5296/jse.v7i2.10734

\begin{abstract}
The purpose of this study aimed to determine the degree of availability of community school standards in public schools in southern region of Jordan from the teachers' views. To achieve the goals of the study, a questionnaire was developed to collect the data. It consisted of four domains for community school: 1) the optimal use of the community resources, 2) community service, 3) students service, and 4) the participation of parents. The sample of the study was chosen randomly which consisted of 547 male and female teachers. The results of the study showed that the degree of the availability of community school standards were moderate. Based on the study results, the researcher came up with several recommendations. The most important one is integrating community standards within the school programs of administrators' evaluation.
\end{abstract}

Keywords: Community School Standards, Teachers' view, Educational Administration, Jordan, Public School. 


\section{Introduction}

Schools are no longer seen as just as an educational institution aimed at teaching and learning, but should be an integrated social system that aims at: 1) serving community, 2) participating in the comprehensive sustainable development and socializing, and 3) raising the efficiency of school outcomes that is able to serve the community and supply it with employees and qualified workforce that can meet the challenges and changes in the technical areas globally and be open to the world with all its dimensions. Ajmi (2000) demonstrated that the partnership between the school and local community institutions is considered as a concept of modern educational community. This concept is based on the principle of mutual and common interests and focusing on this vision. Ajmi added that the educational success of the educational process will only be through constructive cooperation and fruitful partnership with the community institutions. In addition, strengthened relationship and partnership between all parties link the frames of cognitive theory to the school by the community to be practical and realistic (Ajmi, 2000). Ashour (2011) pointed out that the real role of the educational school institution is a social function based on community service to elevate education from being an issue limited to educators within the walls of schools, to social surroundings which all parties participate in it: home, school, community, and local organizations.

The concept-based on interactive system for open coexistence community school and mutual benefits confirms the reality of the contemporary school, which became a reality derived from its openness and its interaction with the issues and the needs of their communities which is considered as positive trend towards excellence (Sultan, 2008). Qadi (2007) stated that the required interaction between the two roles needs school leadership actor depends on the actual participation of all school staff and dealing with community issues. In addition, it needs opening channels of communication to encourage community members to participate in education and implementation of school educational programs and projects. Furthermore, it needs providing students with the life skills necessary for their growth and development, and giving them practical experience to narrow the gap between what students learning in their school and what they practice in their community are also needed. With same sense, Ajmi (2000) added that the development of the complementary relationship between school and community is one of the important factors to activate the role of the school, increase their efficiency and effectiveness to achieve its objectives and utilization of its human and material available resources. In addition, the implementation of educational reform policy through a partnership between the school and community maintains the continuity and sustainability of development, and it has been associated with the success of the school to its community in which they live.

Given this complementary relationship between the school and the community, the school cannot operate in isolation from the social surroundings because it was found to serve the community and save its legacy, and leadership about foreseeing the future (Alowfi, 2002). To achieve these ends its part of the community foundation, the nature of its role requires to link with its institutions (Alowfi, 2002). Joyce and Steven, (2007) stated that the value-added of the positive relationship between the school and community achieve a number of additional 
features in several areas, including school funding, linked to the surrounding environment, take advantage of the capabilities available in the community and the development of positive attitudes towards society.

Hijazi (2002) demonstrated that the function of community school includes educational dimensions relevant to information, knowledge in the daily lives of the students and how to use it in solving their problems and develop their personalities. He added that the first episode in education is a complementary loop in Educational family and a link between home and community. In addition, this means a holistic role of the school beyond the traditional existing framework which depends on the conservation and memorization of knowledge separately from reality regardless to what is going on the community surrounding the school of humans, civilized and intellectual variables. With same sense, Boardman (2001) stated that there are many important goals of educational community school. First, developing students' abilities and their skills based on the local community values. Second, providing them with an integrated system of alternatives in technical learning based on the use of technology and open education for all members of the community. Third, giving families and community members several opportunities to participate in the planning and implementation of many programs, this helps to shift from rigid outlook and closed systems to open environment of schools toward all surrounding fields, socially, economically, cultural and intellectual elements.

Jacobson (2003) addressed many community school priorities. First, the mechanism of reforming educational systems in which they come out of the traditional school into an interactive school with a real partnership to its community. Second, the support and backing of parents and refine academic curriculum, social skills of problem solving, will help face the challenges associated with fast technological changes. Third, delivering effective opportunities for the students through training and mentoring programs by qualified and experienced persons. Fourth, learning how to provide humanitarian and volunteer services and guidance toward productive work. This perception prompted many institutions in the United States for the alliance to support community schools movement (Jacobson, 2003).

Tahir (2007) focused on the importance of establishing a close relationship of cooperation between the school and family to achieve acceptable understanding regarding their roles in child-rearing to getting rid of the majority of the problems that the child may face. In addition, he emphasized on the significance of increasing school understanding to the social, economic, and psychological situations of students which lead to integrate the culture of the community with the culture of the school. This harmony that exists between school and family makes the educational work plan common between both and provides opportunities to clarify their positions better than many school events, and that communities are exposed to changes radically and rapidly in all fields. These factors make the school needs the support of the local community physically and morally (Tahir, 2007).

Mary and Lawernce (2007) pointed out that the multidimensional vision of community schools built on: 1) establishing advisory boards of the school and integrate of parents and community members in the educational process, 2) organizing educational programs, 
including lectures, seminars, and workshops for parents dealing with a variety of social issues, 3) organizing various social activities such as observances, trips, school exhibitions and sports competitions, and 4) expanding learning opportunities for all members of the local community. Sunqur (2005) added that community schools confirm on building a complementary cooperative relationship offers opportunities to serve the community, and contribute to meet its needs and programs of a democratic way, where everyone involved in achieving the educational goals flexibly and positively without stereotypes and tradition. With same sense, Khatib and Khatib (2006) stated that multidimensional vision of community schools reinforces the principle of self-learning and continuous training and participation in decision-making and in the training of teachers by the experts and the training of students in the social institutions to gaining practical skills.

Based on the previous discussion, the researchers can conclude that community school is closely related with its community in terms of the development of the concept of education, and opens horizons to the local community. This represents identity which characterizes the school, to maximize the process of implementing various partnerships with various sectors of society down to create a school environment that touches the rhythm of real life.

\section{Literature Review}

There are several studies discussed the topic of the availability of community schools standards in public schools, as the following:

Atoom and Atoom (2014) conducted a study to investigate the degree of community school application and obstacles from the standpoint of the managers and directors of public schools in Jerash Governorate, Jordan. The study sample consisted of 120 principals at governmental schools. The study showed that the degree of community school application was moderate. In addition, the highest domain implemented was the field of educational services and the lowest one was the field of optimizing the use of resources of the community. Further, the implementation of the community school was faced many obstacles such as the weakness of the incentives for workers, the lack of trained administrative staff, and the work pressure on teachers and administrators.

Martin, Reuben, and Atelia (2012) conducted a study entitled the partnership through the school and the community. This study aimed to identify the role of community leaders in the development of effective and sustainable relationships with community-based school. In addition, it focused on the role of community schools' means in improving the use of partnerships to bring the school and community resources and improving the performance of students from through the active participation of society and build an integrated vision of community schools. Further, it classified the role of community leaders in building effective partnerships with the relevant authorities to identified community schools properties in the development of a common vision and a clear engaging the relevant authorities in the community. Finally, it focused on the importance of building a valuable system to these schools that working on encouraging the use of community data and effective utilization of the resources of the local community. 
Shildan, Saymeh, and Barhoom (2011) conducted a study aimed to explore the reality of communication between the school and local community institutions. The study sample consisted of 299 principals and teachers of secondary schools. The results of the study showed that the reality of cooperation between the school and the community was very low and needs to be strengthened. In addition, they showed that there were significant differences in favor of the function variable, and there were no significant differences regarding variables of qualification, the region, and years of service.

Ashour (2011) held a study to investigate the role of the school director in activating the partnership between the school and the local community in the Sultanate of Oman. The study sample consisted of 513 of workers in the schools and 80 members of the local community. The study concluded that the role of director of the school in activating the partnership between the school and the local community was low, and the order of study domains was as the following: 1) the partnership in the vision and general goals of the educational process, 2 ) the partnership in the provision of financial support for the school, 3) partnership in the administrative affairs of the school, 4) partnership in the provision of consulting services for the school, and 5) partnership in the planning. In addition, the results showed that there were statistically significant differences due to school district variable for all study domains except for the partnership in the administrative affairs of the school. Furthermore, they reveled that there were no statistically significant differences for the "job title" variable to all study domains, with the exception of the partnership in the provision of consultancy for the school and for the directors.

O'Donnell, Kirkner, and Meyer-Adams (2008) conducted a study entitled: low-income, urban consumers' perceptions of community school outreach practices, desired services, and outcomes. The study sample consisted of 113 individuals with low income in urban areas. The results showed that the community schools require the active participation of family and community members in the education of children, whether it was at home or at school. In addition, they showed that there were positive changes in the work environment as a result of the cooperation of the school and the community for their positive participation. Furthermore, they showed that the nature of the successful participation of parents requires strategies to make them aware of the benefits of cooperation with the schools, creating a positive learning opportunities for children and families.

Hamadneh (2007) conducted a study to investigate the degree of estimation of directors of government schools for community participation in the activation of self-management in the schools of the governorate of Irbid in Jordan. The study sample consisted of 605 of directors. The study found that the estimating the principals of community participation in the activation of self-management schools for all dimensions are high. In addition, they indicated that there was no statistically significant difference between the averages due to gender, educational qualification, experience, or the interaction between these variables.

Hamdan and Ansari (2007) conducted a study entitled: posts community to finance educational projects in Kuwait from the standpoint of high school directors. The study results showed that community participation in the funding of educational projects were moderately. 
In addition, there were statistically significant differences due to the gender variable in favor of males. Furthermore, there were no statistically significant differences due to the variable of experience years.

Abu Samra (2006) conducted a study that aimed to identify the perceptions of high school directors and parents in the Hebron district for the interaction between the school administration and the community. The study sample consisted of 60 directors and 390 parents. The results of the study shown that the perceptions of the degree of high school directors and parents -for the interaction between the school administration and the local community- were moderate.

Peterson (2006) held a study that investigated the leadership role of directors in the school professional development. The study aimed to identify the role of the school principals in the evolution of the performance of teachers to deal with the needs of the local community. The study sample consisted of 46 primary schools in the state of Louisiana, US. The study found the following results: 1) the future dimension of the school in dealing with the local community the most important in the field of professional development for teachers, 2) the positive role of parents, 3 ) there were statistically significant differences due to the variable of experience years, and 4) there were no statistically significant differences due to the variable of gender.

Rogers and Wright (2006) conducted a study to evaluate the role of technology in enhancing communication between the school, community, and family. The study aimed to detect the point of view of teachers and parents about the use of modern means of communication in the process of enhancing cooperation between the educational elements of society, school, and family. The study sample consisted of 48 teachers and 162 parents. The study showed the positive effects of communication between the family and the school. In addition, it showed the importance of the role of the communications media in the development of the relationship with the local community. Furthermore, it showed that there were many obstacles that face communication between the school and the community such as the lack of awareness among teachers and parents.

Rex (2005) conducted a study to explore the model of software program for the rehabilitation of elementary school directors in rural areas. The study sample consisted of 120 directors at secondary and High School. The results showed that the school directors have an important role in the development of community projects and to draw students' projects and the problems of the local community. In addition, they showed that there were statistically significant differences in favor of the schools in the cities and in areas rich.

In sum, there are some studies that focused on availability of community school standards in public schools. However, other studies focused on the educational programs and development plans in schools. The researchers benefited from previous studies in developing this study instrument and comparing the results of this study with the other studies.

\section{The Study Problem}

Based on the their experiences in the field of educational management at public schools and 
university levels, the researchers found that there are many barriers prevent schools and local community from playing their real and true roles. First, there is an absence of real standards for the positive relationship between the school and the local community. Second, the parental involvement in school activities and community service -in terms of the preparation of plans for students and their families, and solving the problems of society, violence, abuse, addiction, crime, divorce- is very low. Third, there is small number of workshops that serve the community. Fourth, the existence of the poor communication with the community, and the scarcity of available databases that show the needs of the labor market. Fifth, the lack of programs for talented and creative students, and follow up the academic and social achievements of students. Finally, there is no a positively safe educational climate that allows parents to participate in the planning, discussing issues of student and community, and implementing school programs efficiently and effectively. Based on their previous experiences in the public schools in Jordan, researchers conducted this study to specifically answer the following two questions:

1. What is the degree of availability of community school standards in the southern region of Jordan from the teachers' point of view?

2. Are there statistically significant differences $(\alpha \leq 0.05)$ in the degree of availability of community school standards in public schools in the southern region of Jordan -that consisted of three governorates: Karak, Maan, and Tafila- attributed to governorate and teachers' gender?

\section{The Study Importance}

- Highlighting the school community standards.

- Disclosure of the reality of community participation in education in Jordan

- Help to development of indicators for the positive relationship between the school and the community in light of the school community standards.

- Help to detect potential available to apply community standards and provide positive perception of the relationship between the school and the community.

\section{Study Objectives}

- Identify the community school standards.

- Identify the areas of the partnership between the school and the community in the field of optimal use of available resources strategies to serve the local community, and improve the performance of students, and the participation of parents of students in the planning and implementation of various school events.

- Identify the estimates of school directors in the southern governorates in Jordan for the community school standards.

- Take advantage of the recommendations and proposals aimed at activating and developing the relationship between the school and the community. 
- Identify the extent of awareness of school directors for the community school standards.

\section{Study Limitations}

This study was administered solely on public school teachers in the southern region of Jordan that consisted of three governorates: Karak, Maan, and Tafila. In addition, it was conducted in the academic year 2014/2015. Furthermore, generalization of the study results is limited based on the instruments used to collect data and its psychometric properties of reliability and validity.

\section{Procedural Definitions}

Community School: means that the school and community both work as a part of an integrated, democratic and harmonic environment for achieving the educational goals and community service. The procedural definition is the degree to which teachers get it through their answers to each item of the community school standards instrument.

Southern region of Jordan: means the three governorates located in the south of Jordan, those are: Karak Governorate, Tafila Governorate, and Maan Governorate.

\section{Methodology}

The study used a survey approach. According to Creswell (2009) survey design "provides a plan for a quantitative or numeric description of trends, attitudes, or opinions of a population by studying a sample of that population" (p. 201). So, the researchers developed a questionnaire and distributing it to the study participants.

\section{The study population and sample}

The study population consisted of all teachers in governmental schools in southern region of Jordan for the academic year 2014/2015. Of 10900 teachers spread over three governorates: Karak Governorate, Tafila Governorate, and Maan Governorate. Table (1) shows the distribution of the study population according to governorate and gender.

Table 1. Distribution of the study population according to the variables of the study based on the statistics of Ministry of Education in Jordan for the academic year of 2014/2015

\begin{tabular}{|l|l|l|l|}
\hline Governorate & Gender & \multirow{2}{*}{ Total } \\
\cline { 1 - 3 } & Male & Female & \\
\hline Karak & 1972 & 3622 & 5594 \\
\hline Maan & 917 & 2128 & 3045 \\
\hline Tafila & 814 & 1447 & 2261 \\
\hline Total & 3703 & 7197 & 10900 \\
\hline
\end{tabular}

The study sample was selected by random stratified method, so as to be representative of the original population, as a percentage of $5 \%$. Therefore, it was randomly selected 547 teachers to participate in this study. Table (2) shows the distribution of the study sample according to the 
variables of governorate and gender.

Table 2. Distribution of the study sample according to the variables of governorate and gender

\begin{tabular}{|l|l|l|l|}
\hline Governorate & Gender & \multirow{2}{*}{ Total } \\
\cline { 1 - 3 } & Male & Female & \\
\hline Karak & 181 & 99 & 280 \\
\hline Maan & 107 & 46 & 153 \\
\hline Tafila & 73 & 41 & 114 \\
\hline Total & 361 & 186 & 547 \\
\hline
\end{tabular}

\section{Study Instrument}

To investigate the availability of community school standards, the researchers reviewed the theoretical literature and previous studies related to this study such as Ashour (2011), Hamdan and Ansari (2007), and Atoom and Atoom (2014). The researchers developed questionnaire consisted of 48 items distributed based on four criteria: 1) the optimum use of the resources of the community (10 items), 2) local community service (15 items), 3) students service (13items), and 4) the participation of parents (10 items). It was used Likert Scale: Always $=5$, Often $=4$, Sometimes $=3$, Rarely $=2$, and Never $=1$.

\section{Instrument validity}

To check the validity of the study instrument, it was presented to a group of arbitrators from Tafila technical University and Mutah University in order to determine the extent of the appropriateness of the study instrument and its representation for the purpose it was prepared for. The researchers revised the instrument based on the arbitrators' notes.

\section{Instrument reliability}

The reliability of the study instrument was checked through Cronbach's Alpha Formula and Test-re-Test approach. The instrument of the study was distributed to an exploratory sample 30 of teachers. After three weeks it has been re-applied on the same sample. Table (3) shows the reliability coefficients. 
Table 3. Reliability Coefficients

\begin{tabular}{|l|l|l|}
\hline Domain & Test- re-Test & $\begin{array}{l}\text { Cronbach Alpha } \\
\text { Coefficient }\end{array}$ \\
\hline The optimal use of the resources of the community & 0.82 & 0.81 \\
\hline Community service & 0.88 & 0.87 \\
\hline Students service & 0.85 & 0.83 \\
\hline Participation of parents & 0.81 & 0.82 \\
\hline Total & 0.89 & 0.88 \\
\hline
\end{tabular}

Table (3) showed that the test-re-test reliability of the instrument was 0.89 , and the internal consistency coefficient was 0.88 . In addition, the reliability coefficients values ranged between $0.8-0.88$, and the internal consistency ranged between $0.8-0.87$. Those values were acceptable for conducting this study.

\section{Statistical Treatment}

After collecting the data, it has been emptied and the data process statistically using statistical methods. The means and standard deviations were calculated to answer the first question. In addition, the two-way ANOVA test was used to answer the second question.

The adoption of the following rule on the degree of availability of community school standards:

- If arithmetic means which is located between (1-2.33) is low-degree.

- If arithmetic means which is located between (2.34-3.67) is medium-degree.

- If arithmetic means which is located between (3.68-5) is high-degree.

\section{Results and Discussion}

Results relating to the first question: What is the degree of availability of community school standards in the southern region of Jordan from the teachers' point of view? To answer the first question, the means and standard deviations were calculated for each domain of community school standards in public schools in southern region of Jordan, from the point of view of teachers. Table (4) illustrates this. 


\section{Mll Macrothink}

Table 4. Means and standard deviations for teachers' responses to the availability of community school standards

\begin{tabular}{|l|l|l|l|l|}
\hline Domain & Mean & S. D. & Rank & Degree of availability \\
\hline Students service & 3.52 & .742 & 1 & medium \\
\hline community service & 3.40 & .741 & 2 & medium \\
\hline $\begin{array}{l}\text { The optimal use of the } \\
\text { resources of the community }\end{array}$ & 3.25 & .906 & 3 & medium \\
\hline Participation of parents & 3.24 & .730 & 4 & medium \\
\hline Total & 3.37 & .524 & & medium \\
\hline
\end{tabular}

Table (4) showed that all community school standards were moderate and the overall mean (3.37) and standard deviation (0.524). The "students service" domain had the highest mean (3.52) with a standard deviation (0.742). The domain of "community service" came in the second rank with mean (3.40) and standard deviation (0.741), while the domain of "The optimal use of the resources of the community" came in the third rank with mean (3.25) and standard deviation (0.906). However, the domain of "participation of parents" came in the last rank with mean (3.24) and standard deviation (0.730). These results may due to the belief that the goal of school is preparing students to go to a university, and the major function of schools is focusing on the dimension of knowledge. Further, they may due to the poor participation of voluntary organizations due to some restrictions. Furthermore, they may due to the low level of awareness of the importance of education, and the need to participate in its activities, and the belief that the school has replaced the family. Finally, they may due to the legislation and regulations that limits the nature of positive interaction between the organizations of local community and school. Results of this study agreed with Atoom's study (2014) and Abu Samra's study (2006) which they indicated that the application of the principles of the community school was moderate.

First domain: The optimal use of resources of the community 
Table 5. Means and standard deviations for the responses of teachers on each item of the first domain: "optimal use of the resources of the community"

\begin{tabular}{|c|c|c|c|c|c|}
\hline $\begin{array}{l}\text { Item } \\
\text { No. }\end{array}$ & Item & M. & S. D. & Rank & Degree \\
\hline 2 & $\begin{array}{l}\text { School organizes field trips to factories and } \\
\text { companies according to the school curriculum } \\
\text { requirements }\end{array}$ & 3.70 & 1.315 & 1 & High \\
\hline 10 & $\begin{array}{l}\text { Involve community leaders in the school } \\
\text { committees. }\end{array}$ & 3.52 & 1.036 & 2 & Medium \\
\hline 4 & $\begin{array}{l}\text { Exploit the raw materials with the local community } \\
\text { and using them for the benefit of the educational } \\
\text { process. }\end{array}$ & 3.46 & 1.717 & 3 & Medium \\
\hline 3 & $\begin{array}{l}\text { Have participatory programs with companies and } \\
\text { entrepreneurs from which to support the school (with } \\
\text { equipment ......etc). }\end{array}$ & 3.42 & 1.044 & 4 & Medium \\
\hline 6 & $\begin{array}{l}\text { Form committees from the local community to } \\
\text { collect donations, whether financial or in-kind to } \\
\text { finance its activities, both internal and external. }\end{array}$ & 3.29 & 1.273 & 5 & Medium \\
\hline 8 & $\begin{array}{l}\text { Establish relations with the local community } \\
\text { participatory institutions related to the integrated } \\
\text { development of the students care (such as mosques, } \\
\text { media etc ...) }\end{array}$ & 3.22 & 1.132 & 6 & Medium \\
\hline 1 & $\begin{array}{l}\text { Service institutions require school staff to give } \\
\text { lectures to students }\end{array}$ & 3.18 & 1.055 & 7 & Medium \\
\hline 7 & $\begin{array}{l}\text { Take advantage of the school community institutions } \\
\text { facilities to carry out their activities and events. }\end{array}$ & 2.97 & 1.295 & 8 & Medium \\
\hline 5 & $\begin{array}{l}\text { The school is cooperating with the local community } \\
\text { to carry out its product development projects and } \\
\text { supported. }\end{array}$ & 2.88 & 1.288 & 9 & Medium \\
\hline 9 & $\begin{array}{l}\text { Agreements with institutions of civil society are held } \\
\text { to provide job opportunities for students during the } \\
\text { summer vacation to equip them with practical skills. }\end{array}$ & 2.83 & 1.517 & 10 & Medium \\
\hline \multicolumn{2}{|l|}{ Total } & 3.25 & 0.906 & & Medium \\
\hline
\end{tabular}

Table 5 showed that the total mean of "optimal use of resources of the community" domain was modrate (3.25) and standard deviation (0.906). In addition, the item 2: "School organizes field trips to factories and companies according to the school curriculum requirements" had the highest rank and its mean was (3.70) and standard deviation was (1.315). This may be due 
to the fact that school trips are linked to the recreational aspect of teachers and students, and this cause increasing the students' understanding of some of the concepts in the curriculum. Furthermore, the item 10: "Involve community leaders in the school committees" came in the second rank with a mean of (3.52), and standard deviation (1.036). The Items of 4,3,6,8,1,7,5, and 9 came with moderate degree. This may be due to: 1) the difficulty of concluding agreements with the local community, because of the central and regulations that limit the flexibility of holding such agreements between the school and institutions of local community, and 2) the lack of awareness of the importance of community participation by the community, and the weakness of his contributions in proposing solutions to the problems of the schools.

Second domain: Community service

Table 6. Means and standard deviations for the responses of teachers on each item of the second domain: "community service"

\begin{tabular}{|c|c|c|c|c|c|}
\hline $\begin{array}{l}\text { Item } \\
\text { No. }\end{array}$ & Item & M. & S. D. & Rank & Degree \\
\hline 19 & $\begin{array}{l}\text { The school establishes school student committees } \\
\text { to collect donations and aid and distributed to the } \\
\text { poor and needy in the community. }\end{array}$ & 3.80 & 1.272 & 1 & High \\
\hline 22 & $\begin{array}{l}\text { The school believes in voluntary work to serve } \\
\text { the local community. }\end{array}$ & 3.73 & .977 & 2 & High \\
\hline 14 & $\begin{array}{l}\text { The school open educational facilities (labs, } \\
\text { library, golf ...) to serve the local community. }\end{array}$ & 3.54 & 1.164 & 3 & Medium \\
\hline 17 & $\begin{array}{l}\text { School district considers itself part of the living } \\
\text { reality of the community. }\end{array}$ & 3.52 & 1.315 & 4 & Medium \\
\hline 13 & $\begin{array}{l}\text { The school opens its doors to students and their } \\
\text { families and the community to practice activities. }\end{array}$ & 3.51 & 1.076 & 5 & Medium \\
\hline 21 & $\begin{array}{l}\text { The school has plans and strategies for the } \\
\text { management of communal crises and contributes } \\
\text { to the find solutions. }\end{array}$ & 3.46 & 1.263 & 6 & Medium \\
\hline 15 & $\begin{array}{l}\text { The school outreach programs to solve problems } \\
\text { faced by society (violence, abuse, addiction, } \\
\text { crime, divorce.) }\end{array}$ & 3.45 & 1.067 & 7 & Medium \\
\hline 25 & $\begin{array}{l}\text { Take advantage of the expertise of teachers to } \\
\text { serve the community members in their various } \\
\text { forms }\end{array}$ & 3.43 & 1.164 & 8 & Medium \\
\hline 16 & $\begin{array}{l}\text { Schools relay civilization and cultural variables } \\
\text { to the community and provide feedback about } \\
\text { them. }\end{array}$ & 3.40 & 1.050 & 9 & Medium \\
\hline
\end{tabular}




\section{Mll Macrothink}

Journal of Studies in Education

ISSN 2162-6952

2017, Vol. 7, No. 2

\begin{tabular}{|c|c|c|c|c|c|}
\hline 12 & $\begin{array}{l}\text { The school has plans to train teachers and } \\
\text { students on community participation. }\end{array}$ & 3.37 & 1.053 & 10 & Medium \\
\hline 18 & $\begin{array}{l}\text { The school has programs and educational courses } \\
\text { for adults and children to meet their own personal } \\
\text { needs. }\end{array}$ & 3.23 & 1.080 & 11 & Medium \\
\hline 20 & $\begin{array}{l}\text { The school Open classroom to members of the } \\
\text { community and are considered an integral part of } \\
\text { its philosophy. }\end{array}$ & 3.22 & 1.101 & 12 & Medium \\
\hline 11 & $\begin{array}{l}\text { The school conducted survey studies to determine } \\
\text { the needs of the local community and contribute } \\
\text { to the solution. }\end{array}$ & 3.21 & 1.164 & 13 & Medium \\
\hline 24 & $\begin{array}{l}\text { The school has data on the labor market needs } \\
\text { rules in the future. }\end{array}$ & 3.17 & 1.234 & 14 & Medium \\
\hline 23 & $\begin{array}{l}\text { The school Adopt strategies and actions are } \\
\text { encouraged to communicate with the local } \\
\text { community. }\end{array}$ & 3.01 & 1.400 & 15 & Medium \\
\hline & & 3.40 & .741 & & Medium \\
\hline
\end{tabular}

Table (6) indicated that the total mean for this domain was moderate (3.4), and standard deviation was (0.741). Items 19 and 22 got the highest ranks. The mean of item 19: "The school establishes school student committees to collect donations and aid and distributed to the poor and needy in the community" was (3.80) and standard deviation was (1.272). This result may due to the mainstream of society which assumes that students and religious values are a key component of the community. In addition, school volunteer work, become an indicator for the success of the school and communication with the community. The rest of the items, except items 19 and 22, came with moderate means, and the lowest item was item 23: "The school Adopt strategies and actions are encouraged to communicate with the local community" with a mean of (3.01) and standard deviation (1.400). This result indicated that schools do not commit to develop clear strategies to interact with the local community. This commitment requires high skills, effective planning, good educational leadership that is able to meet the challenges of integration between the school and society. Those results agreed with the study of O'Donnell, Kirkner, and Meyer-Adams (2008), which showed that the nature of the successful participation of parents requires strategies to make them aware of the benefits of cooperation with schools.

Third domain: Students service 
Table 7. Means and standard deviations for the responses of teachers on the third domain: "students service"

\begin{tabular}{|c|c|c|c|c|c|}
\hline $\begin{array}{l}\text { Item } \\
\text { No. }\end{array}$ & Item & M. & S. D. & Rank & Degree \\
\hline 28 & $\begin{array}{l}\text { School instilled in the minds of the students the } \\
\text { importance of volunteer work within the school. }\end{array}$ & 3.87 & 1.115 & 1 & High \\
\hline 37 & The school offers the school climate for students. & 3.81 & 1.662 & 2 & High \\
\hline 36 & The school offers a safe environment for students. & 3.70 & 1.229 & 3 & High \\
\hline 27 & $\begin{array}{l}\text { School offers outreach programs, psychological and } \\
\text { professional for students to adapt to the demands of } \\
\text { life. }\end{array}$ & 3.66 & 1.102 & 4 & Medium \\
\hline 32 & School involved students in all school committees & 3.54 & 1.262 & 5 & Medium \\
\hline 34 & $\begin{array}{l}\text { School has extracurricular programs applied during } \\
\text { the school year. }\end{array}$ & 3.50 & 1.723 & 6 & Medium \\
\hline 35 & $\begin{array}{l}\text { School pursuing student's academic achievements } \\
\text { and evaluation. }\end{array}$ & 3.47 & 1.233 & 7 & Medium \\
\hline 38 & $\begin{array}{l}\text { School applied methods and strategies for teaching a } \\
\text { variety of school curriculum. }\end{array}$ & 3.46 & 1.265 & 8 & Medium \\
\hline 31 & $\begin{array}{l}\text { School listens to the opinions and suggestions of } \\
\text { students constantly. }\end{array}$ & 3.42 & 1.162 & 9 & Medium \\
\hline 29 & $\begin{array}{l}\text { School addresses the needs of students and works to } \\
\text { meet them. }\end{array}$ & 3.41 & 1.278 & 10 & Medium \\
\hline 30 & $\begin{array}{l}\text { The school has programs and strategies for the } \\
\text { detection of the talents of the students and are } \\
\text { meeting them. }\end{array}$ & 3.37 & 1.180 & 11 & Medium \\
\hline 33 & $\begin{array}{l}\text { The school has a variety of programs that focus on } \\
\text { the development of belonging among students to } \\
\text { serve their country. }\end{array}$ & 3.36 & 1.265 & 12 & Medium \\
\hline 26 & $\begin{array}{l}\text { The School has programs for gifted and creators } \\
\text { students. }\end{array}$ & 3.35 & 1.236 & 13 & Medium \\
\hline \multicolumn{2}{|l|}{ Total } & 3.53 & .742 & & Medium \\
\hline
\end{tabular}

Table 7 indicated that mean of the overall items was moderate (3.53) and standard deviation was (0.742). The items of 28, 37, and 36 had the highest ranks, and may this indicates to the achievements within the school, and this much easier than going out to the community field which requires efficiency and effectiveness, patience, and build trust with the local community. In addition, this may be due to the fact that gifted students need a suitable school 
environment and private programs deepening and development of readings and additional means of technological to carry out study projects and programs. All of this requires an effective partnership with the community, and a local support from parents. However, items of $35,38,31,29,30,33,26,27,32$, and 34 had moderate means.

\section{Fourth Domain: Participation of parents}

Table 8. Means and standard deviations for the responses of teachers on the fourth domain: "participation of parents"

\begin{tabular}{|c|c|c|c|c|c|}
\hline $\begin{array}{l}\text { Item } \\
\text { No. }\end{array}$ & Item & M. & S. D. & Rank & Degree \\
\hline 39 & $\begin{array}{l}\text { The school organizes regular meetings with } \\
\text { parents to discuss matters of interest to children. }\end{array}$ & 3.59 & 1.365 & 1 & Medium \\
\hline 46 & $\begin{array}{l}\text { The school involved parents in the evaluation of } \\
\text { school performance results. }\end{array}$ & 3.43 & 1.103 & 2 & Medium \\
\hline 47 & $\begin{array}{l}\text { The school involved parents in extracurricular } \\
\text { activities within the school and beyond. }\end{array}$ & 3.34 & 1.052 & 3 & Medium \\
\hline 41 & $\begin{array}{l}\text { The school organizes regular meetings between } \\
\text { teachers and parents to discuss the multiple } \\
\text { educational issues. }\end{array}$ & 3.29 & 1.188 & 4 & Medium \\
\hline 48 & $\begin{array}{l}\text { The school holds open meetings between teachers, } \\
\text { parents and students to discuss the issues they } \\
\text { face. }\end{array}$ & 3.27 & 1.143 & 5 & Medium \\
\hline 44 & $\begin{array}{l}\text { The school supplies periodically reports to parents } \\
\text { about their children's performance and academic } \\
\text { achievement. }\end{array}$ & 3.15 & 1.181 & 6 & Medium \\
\hline 42 & $\begin{array}{l}\text { The school involved parents in all school } \\
\text { committees. }\end{array}$ & 3.14 & 1.316 & 7 & Medium \\
\hline 45 & $\begin{array}{l}\text { The school has effective ways to communicate } \\
\text { with parents, }\end{array}$ & 3.12 & 1.235 & 8 & Medium \\
\hline 43 & $\begin{array}{l}\text { The school involved parents in the programs and } \\
\text { activities carried out by the layout. }\end{array}$ & 3.02 & 1.040 & 9 & Medium \\
\hline 40 & $\begin{array}{l}\text { The school involved parents in the training } \\
\text { courses given to teachers. }\end{array}$ & 3.01 & 1.353 & 10 & Medium \\
\hline \multicolumn{2}{|l|}{ Total } & 3.53 & .742 & & Medium \\
\hline
\end{tabular}

Table 8 showed that the total mean of all items was moderate (3.53) and standard deviation was (0.742). Item 39: "The school organizes regular meetings with parents to discuss matters of interest to children", had the first rank and the highest mean (3.59), and standard deviation 
(1.365). This result may be due to the meetings that require planning, effort, time, living under pressure till performing school work. However, the item 40: "The school involved parents in the training courses given to teachers" came in the last rank with lowest mean (3.01) and standard deviation (1.353). This indicated to the need: 1) to have a specific data concerning the qualifications and experiences of parents, 2) to explore their willingness to engage in school work and develop the professional and educational culture that able to take advantage of the local community data, and 3) to have a high degree of awareness among teachers and parents. This result agreed with the study of Rogers and Wright (2006).

Results relating to the second question: Are there statistically significant differences $(\alpha \leq 0.05)$ in the degree of availability of community school standards in public schools in the southern region of Jordan -that consisted of three governorates: Karak, Maan, and Tafilaattributed to governorate and teachers' gender? Table (9) shows the values of the means and standard deviations of the total score for the availability of the community school standards in the public schools in the southern governorates according to the governorate variable.

Table 9. Means and standard deviations for the total score values of the degree of availability of community school standards in public schools

\begin{tabular}{|l|l|l|}
\hline Governorate & Mean & St. Deviation \\
\hline Karak & 3.52 & .523 \\
\hline Maan & 3.20 & .494 \\
\hline Tafela & 3.23 & .452 \\
\hline
\end{tabular}

Table (9) showed that the Governorate of Karak had the highest mean regarding to the availability of community school standards, and the value of the mean was (3.52) and standard deviation was $(0.523)$. This result may due to: 1$)$ the location of the Governorate of Karak that is close from the Ministry of Education which facilitates movements of the experts to visit and train administrators work in Governorate of Karak, 2) the awareness of the importance of the role of the school by the local community, and 3) the stability of the educational experiences in Karak. Tafila Governorate came secondly with mean (3.23) and standard deviation (0.452). Finally, Maan Governorate came in the last rank with mean (3.20) and standard deviation (0.494).

To determine the significance of differences, it was used a 2-way ANOVA test. Table (10) shows the results. 
Table 10. The results of 2-way-ANOVA test to determine the differences in the level of the availability of community school standards in the public schools in the southern governorates that are attributed to the variables of gender and governorate

\begin{tabular}{|l|l|l|l|l|l|l|}
\hline Source of Variance & Sum of Squares & df & Mean Squares & F- Value & Sig. & Decision \\
\hline Governorate & 14.338 & 2 & 7.169 & 28.858 & .000 & Sig \\
\hline Gender & 0.289 & 1 & 0.289 & 10.164 & .281 & No. Sig \\
\hline Governorate * Gender & 1.332 & 2 & 0.666 & 2.680 & .069 & No. Sig \\
\cline { 1 - 4 } Error & 134.399 & 541 & 0.248 & & & \\
\cline { 1 - 3 } Total & 149.936 & 546 & & & & \\
\hline
\end{tabular}

Table 10 showed that there were statistically significant differences in the availability of community school standards due to the governorate variable. The value of $\mathrm{P}$ was 28.858 and it was statistically significance at the significance level $(\alpha \leq 0.05)$ in favor of the Governorate of Karak. However, there were no statistically significant differences due to the gender variable and the value of $\mathrm{P}$ was 10.164. In addition, there were no statistically significant differences due to the interaction of the governorate and gender variables, and the value of $\mathrm{P}$ was 2.680 .

To determine the source of differences in teachers' estimates of the degree of availability of community school standards according governorate variable, Scheffe test was used. Table (11) shows that.

Table 11. The results of the Scheffe test for dimensional comparisons of the differences in teachers' estimates to the degree of availability of community school standards according to governorate variable

\begin{tabular}{|l|l|l|l|}
\hline Governorate & Karak & Maan & Tafela \\
\hline Karak (3.52) & - & $0.3247^{*}$ & $0.2918^{*}$ \\
\hline Maan (3.20) & $0.3247^{*}$ & - & 0.0328 \\
\hline Tafela (3.23) & $0.2918^{*}$ & 0.0328 & - \\
\hline
\end{tabular}

Table 11 showed that the differences between means of Karak Governorate and Maan Governorate were statistically significant $(0.3247)$ in favor of Karak Governorate. In addition, the differences between means of Karak Governorate and Tafila Governorate were statistically significant (0.2918). However, the differences between the means of Maan Governorate and Tafila Governorate were not statistically significant (0.0328). Given previous indicated that differences in teachers' estimates of the degree of availability of community school standards are in favor of Karak Governorate.

\section{Conclusion}

The purpose of this study aimed to determine the degree of availability of community school 
standards in public schools in southern region of Jordan, from the teachers' views. The results indicated that all community school standards were moderate, and the "students service" domain had the highest mean, then the domain of "community service", after that the domain of "the optimal use of the resources of the community", and the last one was the domain of "participation of parents. In addition, they showed that the degree of availability of community school standards in the southern region of Jordan was moderate. Furthermore, there were statistically significant differences attributed to governorate variable in favor of Karak Governorate.

\section{Recommendations}

Based on the study results, the researches recommend the following.

1. Including the standards of the community school within the programs of evaluation of school principals.

2. Introducing the local community to the activities of the school through bulletins, periodicals, exhibitions and visits.

3. Encouraging school principals to participate in conferences and seminars that discuss the reality of communication between school and society.

4. Educating school principals about the importance of partnership between school and society through training courses.

5. Emphasizing on the importance of involving students and teachers in volunteer work in order to increase the degree of communication with the community.

\section{References}

Abu Samra, M. (2006). Perceptions of secondary school directors and parents in the Hebron district of the interaction between the school administration and the community. Journal of Hebron University for Research, 2(2), 140-163.

Ajmi, M. H. (2000). The school administration. Cairo, Dar Al-Fikr Al-Arabi.

Alowfi, M. (2002). The role of the modern school in the service of the local community. Journal of Education-Ministry of Education in Sultanate Oman, 1, 79-86.

Ashour, M. (2011). The role of school principal in enhancing the partnership between school and community in the Sultanate of Oman. Dirrasat, Jordan University, 38, 2205-1225.

Atoom, Y., \& Atoom, H. (2014). Degree of implementation and the obstacles of the community school from the point of view of government schools managers in Jerash Province. Journal of An-Najah University for Researches (Humanities), 28(4), 707-740.

Boardman, J. (2001). Best practice in community participation in education: Impact and sustainability. Community School Alliance. Retrieved on September 3, 2011 from: http://www.edu.org. 
Creswell, J. W. (2009). Research design: Qualitative, quantitative, and mixed methods approaches. Los Angeles: Sage.

Hamadneh, M. (2008). Public schools principals' assessment degree of social participation in activating self management in Irbed Province schools. Unpublished doctoral dissertation, Yarmouk University, Jordan

Hamdan, M., \& Ansari, I. (2007). Societal participations in financing educational projects for secondary schools in the State of Kuwait: Reality \& hope. Journal of the Gulf and Arabian Peninsula Studies, 33(125), 64 - 85.

Hijazi, A. (2002). The degree of role practice by secondary school principal in serving local community as perceived by teachers and parents in Irbid. Unpublished M.Sc. dissertation, Yarmouk University, Irbid, Jordan.

Jacobson, L. (2003). Community school earns plaudits, but face perils. Education Week, 36(22), 12.

Joyce, E., \& Steven, S. (2002). Present and accounted for: Improving students' attendance through family and community involvement. The Journal of Educational Research, 5(95), 305-319.

Khatib, A., \& Khatib, R. (2006). Community school and education in the future. Irbid, Amman, Alam Al-kutb Al-Hadith for publication and distribution.

Martin, B., Reuben, J., \& Atelia, M. (2012). Achieving results through community school partnership: How district and community leaders are building effective, sustainable relationship. Center for American Progress, Washington.

Mary, A., \& Lawrence, p. (2001). Developing community empowered school. Crowin Press, Inc, Sage Publications Company, California.

O'Donnell, J., Kirkner, S., \& Meyer-Adams, N. (2008). Low-income, urban consumers' perceptions of community school outreach practices, desired services, and outcomes. School Community Journal, 18(2), 147-164.

Peterson, R. (2006). Planning producers and leadership role of the principle in professional development school. Unpublished dissertation, Ball State University.

Qadi, K., (2007). Our curriculum in the new century. Beirut, Lebanon: World of Books.

Rex, H. (2005). Reform of principal certification program focus on urban elementary principle. Dissertation Abstract International, 52(7).

Rogers, R., \& Wright, V. (2006). Assessing technology's role in communication between parents and middle schools. Electronic Journal for the Integration of Technology in Education, 7, 36-58.

Shildan, F., Saymeh, S., \& Barhoom, A. (2011). The reality of communication between the high school and the local community in Gaza Strip and ways to improve it. Fourth 


\section{Macrothink}

Journal of Studies in Education

ISSN 2162-6952 2017, Vol. 7, No. 2

Educational Conference "Educational Communication and Dialogu. The Islamic University, Gaza. October 30-31.

Sultan, F. (2008). Cooperation between school and local community in Riyadh area, Saudi Arabia: Current relation and mechanisms for improvement. Saudi Educational and Psychological, 31, 2-5.

Sunqur, S. (2005). Community school. Damascus, Syria: Dar Alfikr Publishing.

Tahir, R. (2007). Planning for the integration between the innovated units at schools in Egypt and the community participation. Unpublished doctoral dissertation, Cairo University, Egypt. 